\title{
PREDICTING THE EFFICIENCY OF COMMERCIAL BANKS IN BANGLADESH
}

\author{
Md. Golam Solaiman \\ Research Fellow \& In-Charge (Inventory, Purchase \& Procurement) \\ Registrar Office (Admin Branch) \\ Bangladesh Army International University of Science and Technology, Bangladesh \\ E-mail: solaiman19931@gmail.com
}

Md. Shahnur Azad Chowdhury

Associate Professor

Department of Business Administration

Int'l Islamic University Chittagong, Bangladesh

E-mail: tipu_iiuc@yahoo.com

Basharat Hossain

Assistant Professor

Department of Business Administration

Int'l Islamic University Chittagong, Bangladesh

E-mail:m_basarat06@yahoo.com

\section{Sultana Akter \\ Assistant Professor}

Department of Business Administration

Int'l Islamic University Chittagong, Bangladesh

E-mail: sa_maya@ rocketmail.com

Md. Kazi Golam Azam

Assistant Professor

Department of Business Administration

Int'l Islamic University Chittagong, Bangladesh

E-mail: mdkgazam@iiuc.ac.bd

\begin{abstract}
This paper examines the efficiency of the thirty-six commercial banks (27 Domestic and 9 Foreign Banks) by reviewing Literature and analyzing 6 years (2011-2016) data. The sample was selected based on the availability of data. It is assumed that the banking sector complies with the variable returns to scale (VRS) approach which means the output of a bank is not proportionately related to its inputs. Therefore, VRS in the 'Data Envelop Analysis (DEA)' technique has been employed in this paper. The findings reveal that most (30 banks out of 36 banks) of the banks of Bangladesh are inefficient in terms of technical, allocative, and scale efficiency during the 2011-2016 periods. Conversely, only six banks (4 domestic banks and 2 foreign banks) were found efficient in overall scores in this scrutinization. This
\end{abstract}


study did not find any single bank as efficient in all categories (allocative efficiency, technical efficiency, pure efficiency ratio) for the whole study period (2011-2016). This paper provides valuable intuition, analysis, and comments to the managers and policymakers of the bank's efficiency score so that they comprehend their position. Finally, this paper suggests necessary steps to transform the inefficient banks into efficient banks, and to make stable the banking sector of Bangladesh.

Keywords: DEA, Efficiency, Technical Efficiency, Productivity Growth, Domestic \& Foreign Commercial Banks.

JEL Classification Codes: E51, G21, M1.

\section{INTRODUCTION}

Bangladesh is the $35^{\text {th }}$ largest economy in the world having $\$ 2227$ per capita national income according to International Monetary Fund (2021), The Financial Express (2021), and Hossain and Wadood (2020). The economy's real sector comprises the agriculture and Industry sector respectively. The industry sector contributes the largest portion (24.18\%) to GDP in Bangladesh followed by the agriculture and forestry sector $(9.83 \%)$ respectively according to BER (2020). The financial sector consists of monetary intermediation like Banks, Insurance companies, and other financial auxiliaries such as Non-bank Financial Institutions and Microfinance institutions. Currently, 61 banks, 34 Non-bank Financial Institutions, 62 Insurance companies, and 702 microfinance Institutions are providing financial services in Bangladesh according to the report of Bangladesh Bank, 2021, (MRA, 2020). The banking industry of Bangladesh comprises 61 scheduled banks in which 58 are commercial banks including 10 full-fledged Islamic banks while 3 are a specialized bank) and 5 non-scheduled banks. Table- 1 highlights the structure of the banking sector of Bangladesh (Bangladesh Bank, 2021).

Table 1. An Overview of the Banking Sector of Bangladesh

\begin{tabular}{|l|l|l|}
\hline SL. No. & Types of banks & Number \\
\hline 1 & Scheduled Banks & 61 \\
\hline \multirow{3}{*}{$\begin{array}{l}\text { Banks } \\
\end{array}$} & State Owned Commercial Banks (SOCBs) & 6 \\
\cline { 2 - 3 } & Specialized Banks (SDBs) & 3 (agriculture \& Industry development) \\
\cline { 2 - 3 } & Private Commercial Banks (PCBs) & $\begin{array}{l}43 \text { (33 interest based conventional banks, } 10 \\
\text { interest-free Islamic banks) }\end{array}$ \\
\cline { 2 - 3 } & Foreign Commercial Banks (FCBs) & 9 \\
\hline 2 & Non-scheduled banks & 5 \\
\hline 3 & Total Number of Banking Branches & 10752 (at the end of 2020) \\
\hline 4 & Total amount of Banking Deposits & BDT 12904724 million (at the end of 2020) \\
\hline 5 & Total amount of Loan Disbursements & BDT 11449073 million (at the end of 2020) \\
\hline 6 & Total Number of Banking employees* & 182610 (at the end of 2020) \\
\hline
\end{tabular}

Source: Bangladesh Bank (2020), Bangladesh Bank (2021), Sarker (March 16, 2020)

The share of the financial sector to GDP is $3.39 \%$ while only the banking industry contributes to GDP only $2.91 \%$ shown in figure 1 (BER, 2020). The Banking industry is well-structured industry in the financial sector and occupies the maximum portion of formal financing. The banking industry offers several types of demand and time deposits including innovative banking such as school banking, women's banking, agent banking, etc. it also offers a large number of multi-versioned loan and investment banking including consumer banking, auto \& housing, education, eco banking, microfinance, etc. Moreover, SMS 
banking, online banking, i-banking, phone banking, mobile banking, are the most common form of modern banking are facilitated by the banking industry of Bangladesh.

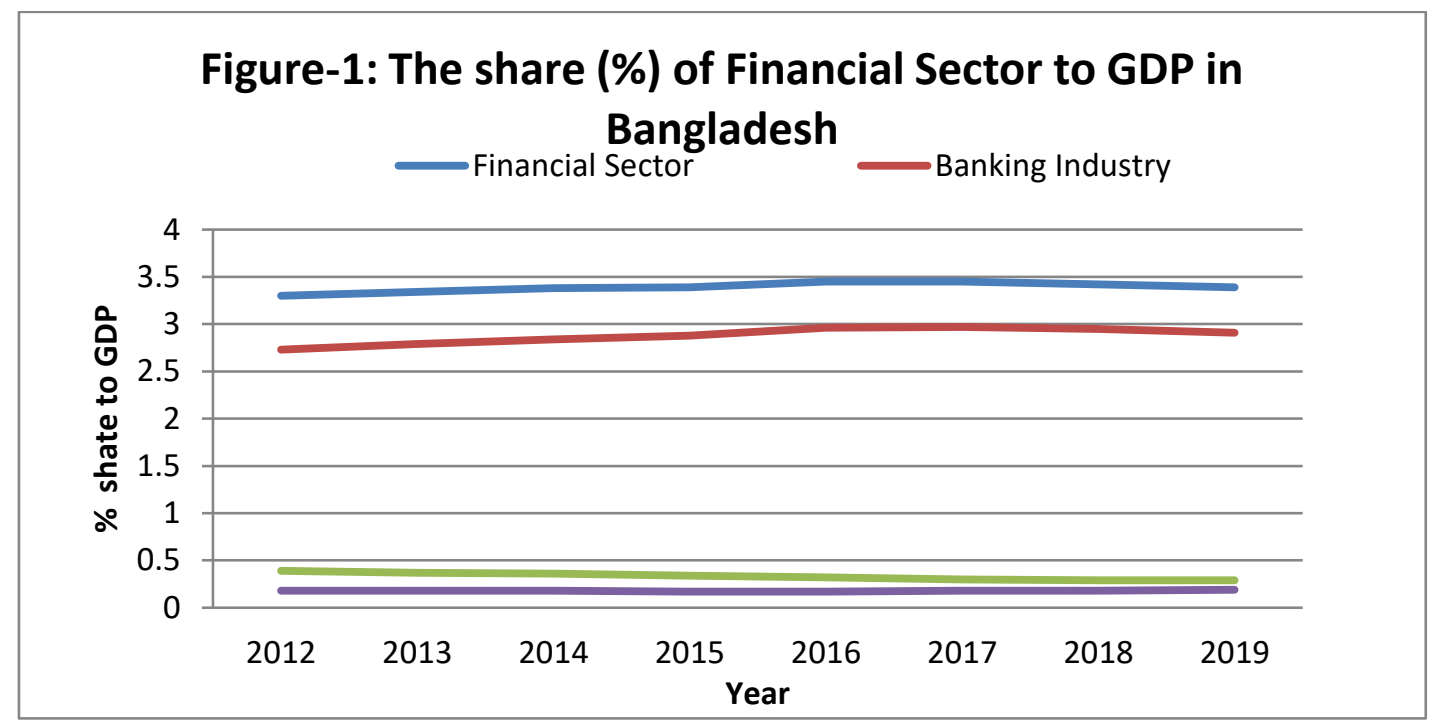

Figure 1. The share of financial sector to GDP in Bangladesh (Source: BER, 2020)

On the contrary, the banking industry of Bangladesh suffers from capital deficits, low-quality asset, loan defaults, lack of transparency, nonperforming loan (NPL), lack of accountability and good governance, not complying with the central bank's standard for loan distribution, customer education, etc. during the recent years (Mahmood, 2019).

However, it should be mentioned that Banks are the prime intermediaries for fund mobilization from financial institutions to the production sector (Hossain, 2019). The smooth and sustainable funding capacity depends on the efficiency of a bank. The earlier research findings dictate that Bank efficiency depends on cost efficiency (Girardone, Molyneux, \& Gardener, 2004), profitability (Sufian \& Kamarudin, 2014), Returns on Asset (ROA), Returns on Equity (ROE), Capitalization of banks (Mirzaei, Moore, \& Liu, 2013), total loans and assets management, diversification in operations and income, favorable banking environment (Sufian, Kamarudin, \& Noor, 2013), skilled Human resources (Mohammad Masum et al., 2015), and bank assets and equity (Solaiman et al., 2017). Also, the good and efficient banks not only expanding productivity but also controls and maintain the economic shocks and gaps (Athanasoglou et al., 2008). The aim of this paper is to scrutinize the bank efficiency of the 36 selected commercial banks of Bangladesh.

\section{OBJECTIVES OF THE RESEARCH}

The main objective of this paper is to analyze the bank efficiency of the 36 selected commercial banks of Bangladesh. More specifically,

- To give an overview of the banking industry in Bangladesh.

- To measure the actual performer bank on banking sectors in Bangladesh.

- To evaluate the technical efficient bank and also highest productivity growth bank in Bangladesh.

\section{OVERVIEW OF THE LITERATURE}

Many studies show the banking sector's performance by different methods and variables for their findings. Kalsie et al. (2020) stated that financial stability doesn't depend on one variable. It depends on 
four measurements of financial stability under two stages. The efficient banking environment is a major part and also an important issue for Bangladesh bank in order to strengthen supervision, monitoring, and regulation (Sufian \& Kamarudin, 2014). The ownership is not relating factor for measuring bank efficiency and domestic private banks is more efficient than government own banks (Bonin, Hasan, and Wachtel 2005). Most of the studies worked only measuring efficiency on the banking sector in Bangladesh in their respective papers or task, but they did not evaluate the financial crisis impacts in which created a crucial or negative effect on the banking sector in Bangladesh (Masood \& Ashraf, 2012). In 2015, Masum and Azad examined that how skilled human resources increase the bank's efficiency and performance. Another study shows that strong bank assets and equity helps to efficient score where any financial crisis could not hit bank's profits and growths (Azad et al., 2017). Akber (2019) discussed in his study that bank's performance depended on internal and external factors by analyzing six sample Banks from Bangladesh. Another study shows a comparative performance analysis especially technical efficiency between Islamic banks and commercial banks in Bangladesh where conventional banks technically more efficient rather than Islamic banks in Bangladesh (Samad, 1999). Found in this study conventional bank's efficiency mean ratio was $62.8 \%$ where Islamic banks in our country's technical efficiency mean ratio was $59.6 \%$. But the mean ratio of deposits was .60 and .61 percent respectively. In another's study shows the ratio of technical efficiency between $98.4 \%$ and $99.5 \%$ in the Islamic banking industry of Bangladesh from 2008 to 2012 (Samad, 2019). In 2015 Azizul Baten finds that the technical and allocative efficiency average ratio was $35.09 \%$ and $74.0 \%$ of online banking sectors by DEA cost while DEA profit margin ratio was 31.8 and 74.0 percent. And also found that technical efficiency and productivity changing ratio was decreased on average 5.1 percent and 4.2 percent respectively (Baten $\&$ Mat Kasim, 2015). Another study found that the income and cost efficiency ratio was increased in this study's periods. Its ratio was 37.84 and 15.28 percent in 2015. In 2012 a study found that efficiency scores are equal to one of few commercial banks in Bangladesh but one bank is achieved as a benchmarked score Southeast Bank Ltd among selected banks in Bangladesh (Rashedul \& Israt, 2012). In this study, the bank used all valid and legal documents. In 2017 another study showed their empirical study that the banking sector was the highest efficiency level but the efficiency level was shut down in 2010 for scale and global financial crisis effects (Banna, Ahmad, \& Koh, 2017). Haddad et al. (2019) found a positive relationship has existed between ownership structure and bank performance. To find this result the study conducted by an analysis Ordinary Least Square method on two groups of data set such as 63 conventional banks and 63 Islamic banks from 16 countries. For a large rate of inflation, the banking sector declined its efficiency level and performance where spread margin was negatively decreased (Suzuki \& Adhikary, 2010). But another study found that the private banking sector in our country was not only remarkably developed on their efficiency scale but also positively changed their productivity scale for financial deregulation changing activities by the central bank in Bangladesh (Uddin \& Suzuki, 2014). A study was conducted on the Indian banking industry to evaluate bank efficiency through Data Envelopment Analysis (DEA) method to compare the efficiency of the public, private, and foreign banks. The result of this study found that public banks are more efficient than private and foreign banks in India (Tanwar et al., 2020). Besides, Bank efficiency also varies with the performance of Non-Performing Loans of banks. In this regard, a study on Nepalese Bank to examine the bank internal and macroeconomic factor effect the performance of Non-Performing loan using ordinary regression square model on 50 samples of the bank for the period 2013-2017 (Bhattarai, 2018).

\section{METHODOLOGY}

Data Envelopment Analysis (DEA) is an effective and new approach for measuring performance and is also called a non-parametric mathematic programming approach to frontier estimation. It is mathematical 
programming that maintaining a large number of variables and relations (Constants). This paper applies the Data Envelopment Analysis (DEA) to measure the efficiency of 36 sample banks. The Data Envelopment Analysis (DEA) assesses the efficiency and performance of non-profit and public sector institutions. It assists a relationship between analysts and decision-makers which collaboration with inputs and outputs. By using a DEA method, a firm can analysis or measuring its performance and the efficiency levels to utilize its inputs. For measuring the efficiency of a firm, DEA is the best approach and performer method according to Berger and Humphrey (1997). DEA method used to measure the productivity efficiency that's are consisted of technical efficiency (TE), Allocative efficiency (AE), Scale efficiency (SE), and pure technical efficiency (PTE). Here TE identifies the performance and ability of a firm to maximize the level of outputs by utilizing a minimum level of inputs. Which is equal to one. It will be taken value between 0 and 1 . AE means reflects the ability of a firm to use the input in optimal proportions given their respective prices. Scale Efficiency (SE) means the proper uses of input ratio by which gets optimal proportions a firm, pure efficiency (PE) means the ability of a firm that input must be converted into output. PTE efficiency is not only reflecting best performance but also measures the effectiveness of management production plans of firm size. However, this study will try to measure the performance and productivity capacity of the selected commercial banks in Bangladesh by taking some performance relevant activities as inputs. Estimating TE, AE, SE, and PTE efficiency levels. DEA programs use two (Zero and One) mathematical values for measuring efficiency and inefficiency performance for a firm. Hence zero (0) value represents the inefficient position and one (1) value indicated the efficient position of a firm. This study found that many studies used different individual methods for measuring banking performance like CAMELS rating and Regression analysis. This is a very effective method for identifying specific banking performance for example Capital adequacy, Asset quality, management, earnings, and liquidity, etc. Total factor productivity and index summary are the most popular element in the DEA method for estimating the bank efficiency position (Sozen \& Alp, 2013).

\section{Data Sources and Samples}

This paper employed secondary data over the 2011-2016 periods for measuring the bank efficiency of 36 Bangladeshi banks. This study collects data from different sources such as Bangladesh Banks, bank scopes, and individual banks web sites, Google storage, etc.

The population of this study is 61 banks of Bangladesh while 36 banks of Bangladesh are selected as the sample according to the availability of the information for evaluating the bank efficiency and efficiency score. 27 Domestic and 9 Foreign Banks are included in the 36 sample banks.

Furthermore, this study includes three outputs and three inputs. Here 'Off-balance sheet, Interest Income, and total loans' are used as output. And 'total equity, total deposit, and total earning assets' are used as inputs in this study.

\section{Description of the Variables}

Table 2. List of Variables and Its Descriptions

\begin{tabular}{|l|l|l|}
\hline SL. No. & Variables Names & \multicolumn{1}{c|}{ Definitions } \\
\hline 01 & Off-Balance Sheet & Sum of issued all financial securities and derivatives items. \\
\hline 02 & Interest Income & The sum of loans, interest on deposits, and interest on many market securities. \\
\hline 03 & Loans & $\begin{array}{l}\text { Including individual loan, commercial loans, consumer loan and industrial } \\
\text { loan, and non-performing loans }\end{array}$ \\
\hline 04 & Equity & The shareholders' claim on the assets of banks. \\
\hline
\end{tabular}




\begin{tabular}{|l|l|l|}
\hline 05 & Deposit & The sum of demands, saving, and time deposits. \\
\hline 06 & Earning Assets & $\begin{array}{l}\text { It directly generates income, such as stocks, interest, dividends formula: } \\
\text { (Assets at the beginning of the year + Assets at the end of the year) / } 2\end{array}$ \\
\hline
\end{tabular}

\section{RESULTS AND DISCUSSION}

This section analyses the results obtained from the DEA and Malmquist DEA calculations. It includes the output oriented efficiency scores obtained from the VRS and CRS model applied to the 36 commercial banks in Bangladesh. The graphical analysis is illustrated by DEAP (software) and the DEA method.

The overall bank efficiency indicates the combination of all efficiency such as allocative efficiency, technical efficiency, pure efficiency, and scale efficiency, etc. according to the DEA method. The standard efficiency score is 1 . If any banks run over 0 and below 1 then this bank is considered inefficient, while a bank having score equal to 1or more than 1 is considered as an efficient bank. This ratio indicates a better performer bank.

\section{Efficient Banks}

The results show that only six banks ( 4 domestic banks and 2 foreign banks) are efficient position due to the proper combination of input and outputs. Of which, two banks are in the best position in Bangladesh during the study periods. One is a foreign commercial bank (Standard Chartered Bank, Score 1.658) and another is a Bangladeshi Commercial Bank (Dutch Bangla Bank Limited, Score 1.035). And rests of the efficient banks are HSBC Ltd (Score: 1.258), AB Bank Limited (Score: 1.034), BRAC Bank Limited (Score: 1.058), and Islami Bank Bangladesh Limited (Score: 1.021).

Table 3. The list of efficient banks in Bangladesh for 2011-2016 Periods: Overall bank efficiency values: Malmquist index summary data table

\begin{tabular}{|r|l|l|l|l|l|l|}
\hline $\begin{array}{l}\text { SL. } \\
\text { No. }\end{array}$ & $\begin{array}{l}\text { Banks (Domestic Banks \& } \\
\text { Foreign Banks) }\end{array}$ & $\mathbf{2 0 1 1 - 1 2}$ & $\mathbf{2 0 1 2 - 1 3}$ & $\mathbf{2 0 1 3 - 1 4}$ & $\mathbf{2 0 1 4 - 1 5}$ & $\mathbf{2 0 1 5 - 1 6}$ \\
\hline 1. & AB Bank Limited & 0.913 & 0.958 & 0.856 & 0.975 & 1.034 \\
\hline 2. & BRAC Bank Limited & 0.891 & 0.956 & 0.963 & 0.986 & 1.058 \\
\hline 3. & Dutch Bangla Bank Limited & 0.942 & 0.895 & 0.936 & 1.195 & 1.035 \\
\hline 4. & Islami Bank Bangladesh Limited & 1.017 & 0.963 & 0.986 & 1.356 & 1.021 \\
\hline 5. & HSBC Limited & 1.074 & 0.975 & 0.956 & 0.916 & 1.258 \\
\hline 6. & Standard Chartered Bank & 1.196 & 1.207 & 1.035 & 0.975 & 1.658 \\
\hline
\end{tabular}

Inefficient Scale: 0 to <1, Efficient Scale: Greater than 1

However, eight banks were found efficient in single or double years before 2016 but detached from their efficient position to inefficient position in 2016 because of changing allocative efficiency, technical efficiency, and scale efficiency values shown in Table 4.

Table 4. List of Bank falling from efficient to Inefficient Position between the years

\begin{tabular}{|r|l|l|l|l|l|l|}
\hline SL & $\begin{array}{l}\text { Banks (Domestic Banks \& } \\
\text { Foreign Banks) }\end{array}$ & $\mathbf{2 0 1 1 - 1 2}$ & $\mathbf{2 0 1 2 - 1 3}$ & $\mathbf{2 0 1 3 - 1 4}$ & $\mathbf{2 0 1 4 - 1 5}$ & $\mathbf{2 0 1 5 - 1 6}$ \\
\hline 1. & Bank Asia Limited & 0.897 & 0.919 & 1.119 & 0.963 & 0.995 \\
\hline 2. & Mercantile Bank Limited & 0.890 & 0.886 & 0.819 & 1.2587 & 0.975 \\
\hline 3. & NRB Commercial Bank Limited & 0.721 & 0.819 & 1.058 & 0.975 & 0.854 \\
\hline 4. & NRB Global Bank Limited & 0.602 & 0.675 & 0.948 & 1.245 & 0.756 \\
\hline
\end{tabular}




\begin{tabular}{|c|l|l|l|l|l|l|}
\hline 5. & The City Bank Limited & 0.886 & 0.975 & 0.927 & 1.006 & 0.975 \\
\hline 6. & Citibank NA & 1.213 & 1.197 & 0.917 & 1.086 & 0.931 \\
\hline 7. & National Bank of Pakistan & 0.991 & 0.975 & 1.236 & 0.867 & 0.948 \\
\hline 8. & State Bank of India & 0.863 & 0.823 & 1.012 & 0.945 & 0.845 \\
\hline
\end{tabular}

Inefficient Scale: 0 to <1, Efficient Scale: Greater than 1

\section{Inefficient Banks}

The following 22 banks were inefficient during the whole study period (2011-2016). These bank's efficiency value was found below one for all periods.

Table 5. The list of inefficient banks in Bangladesh for 2011-2016 Periods: Overall bank efficiency values: Malmquist index summary data table

\begin{tabular}{|c|c|c|c|c|c|c|}
\hline $\begin{array}{l}\text { SL. } \\
\text { No. }\end{array}$ & $\begin{array}{l}\text { Banks (Domestic Banks \& } \\
\text { Foreign Banks) }\end{array}$ & 2011-12 & 2012-13 & 2013-14 & 2014-15 & $2015-16$ \\
\hline 1. & Eastern Bank Limited & 0.537 & 0.819 & 0.895 & 0.819 & 0.895 \\
\hline 2. & IFIC Bank Limited & 0.515 & 0.675 & 0.956 & 0.819 & 0.975 \\
\hline 3. & Mutual Trust Bank Limited & 0.573 & 0.819 & 0.845 & 0.897 & 0.924 \\
\hline 4. & National Bank Limited & 0.641 & 0.687 & 0.986 & 0.895 & 0.928 \\
\hline 5. & NCC Bank Limited & 0.790 & 0.865 & 0.986 & 0.819 & 0.831 \\
\hline 6. & NRB Bank Limited & 0.595 & 0.895 & 0.916 & 0.975 & 0.745 \\
\hline 7. & One Bank Limited & 0.713 & 0.775 & 0.975 & 0.986 & 0.958 \\
\hline 8. & Prime Bank Limited & 0.7884 & 0.827 & 0.927 & 0.986 & 0.943 \\
\hline 9. & Pubali Bank Limited & 0.661 & 0.775 & 0.975 & 0.996 & 0.976 \\
\hline 10. & Southeast Bank Limited & 0.752 & 0.895 & 0.975 & 0.963 & 0.895 \\
\hline 11. & Trust Bank Limited & 0.891 & 0.897 & 0.975 & 0.819 & 0.874 \\
\hline 12. & United Commercial Bank Limited & 0.838 & 0.895 & 0.975 & 0.975 & 0.986 \\
\hline 13. & Uttara Bank Limited & 0.729 & 0.819 & 0.927 & 0.975 & 0.986 \\
\hline 14. & Al-Arafah Islami Bank Limited & 0.650 & 0.795 & 0.963 & 0.927 & 0.916 \\
\hline 15. & EXIM Bank Limited & 0.661 & 0.775 & 0.956 & 0.975 & 0.916 \\
\hline 16. & First Security Islami Bank Limited & 0.628 & 0.805 & 0.936 & 0.975 & 0.856 \\
\hline 17. & ICB Islamic Bank & 0.439 & 0.486 & 0.975 & 0.963 & 0.963 \\
\hline 18. & Shahjalal Islami Bank Limited & 0.617 & 0.956 & 0.825 & 0.836 & 0.936 \\
\hline 19. & Social Islami Bank Limited & 0.656 & 0.936 & 0.817 & 0.981 & 0.875 \\
\hline 20. & Bank Alfalah & 0.596 & 0.897 & 0.897 & 0.986 & 0.751 \\
\hline 21. & Commercial Bank of Ceylon & 0.718 & 0.795 & 0.958 & 0.986 & 0.957 \\
\hline 22. & Habib Bank Limited & 0.697 & 0.819 & 0.963 & 0.916 & 0.965 \\
\hline
\end{tabular}

Source: Author's Calculation, Inefficient Scale: 0 to <1, Efficient Scale: Greater than 1

\section{Efficient Banks Regarding Technical Efficiency}

Technical efficiency is a very essential part for any financial institution for operating their smooth operations and also financial transactions. 


\section{Domestic Banks}

Most of the commercial banks in Bangladesh are technically inefficient but they are making a very competitive banking environment in Bangladesh through their innovative activities from 2011 to 2016. And this study finds that only three banks are inefficient position technically such as Dutch Bangla Bank Limited (DBBL) (Score: 1.56), Bank Asia Limited (Score: 1.058), and NRB Commercial Bank Limited (Score: 1.219) shown in Figure 2. In Bangladesh, the highest technical efficient domestic commercial bank is Dutch Bangla bank Ltd. and the lowest technical efficient banks are social Islamic bank (Score: 0.817 ) and mercantile bank ltd. (Score: 0.819).

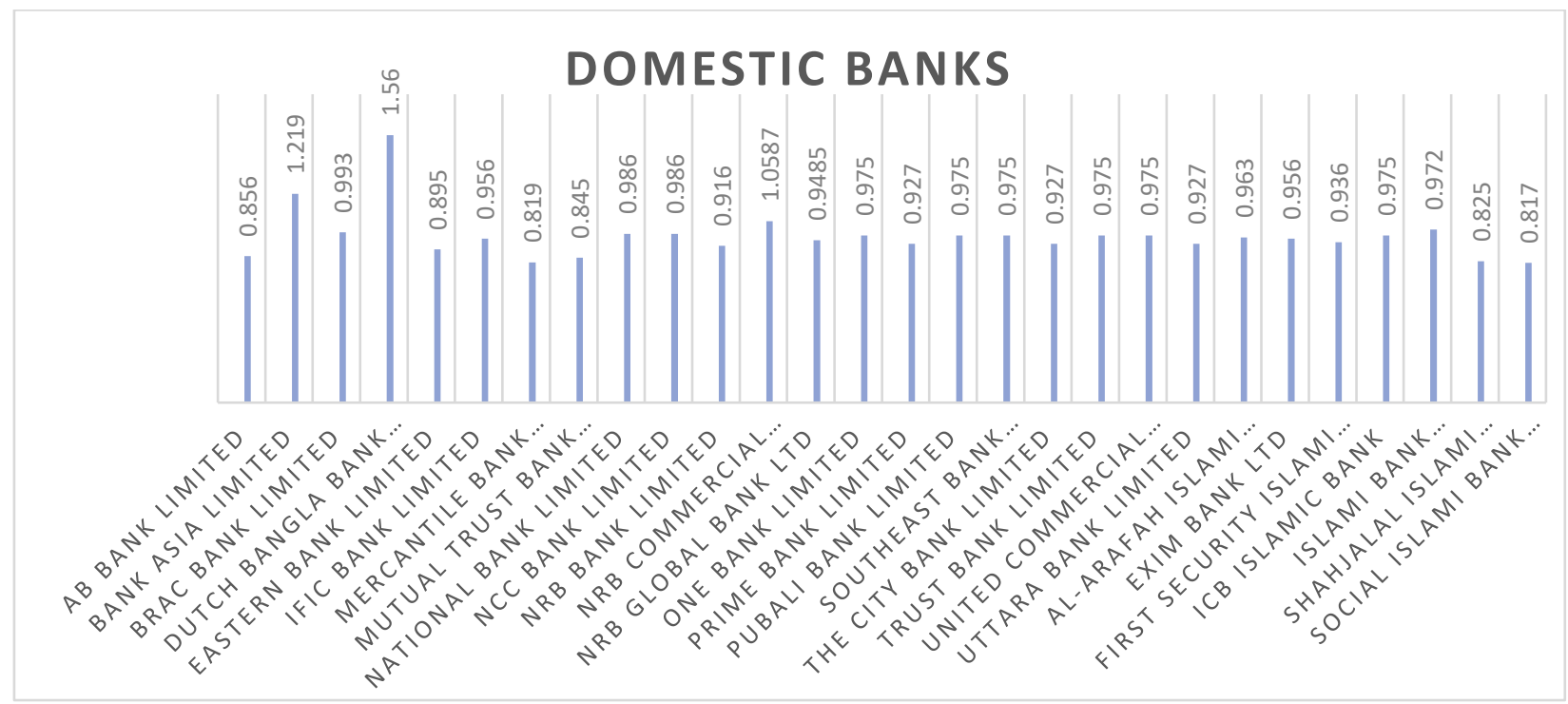

Figure 2. Performance of Foreign Banks' efficiency regarding the technical efficiency

\section{Foreign Banks}

\section{FOREIGN BANKS}

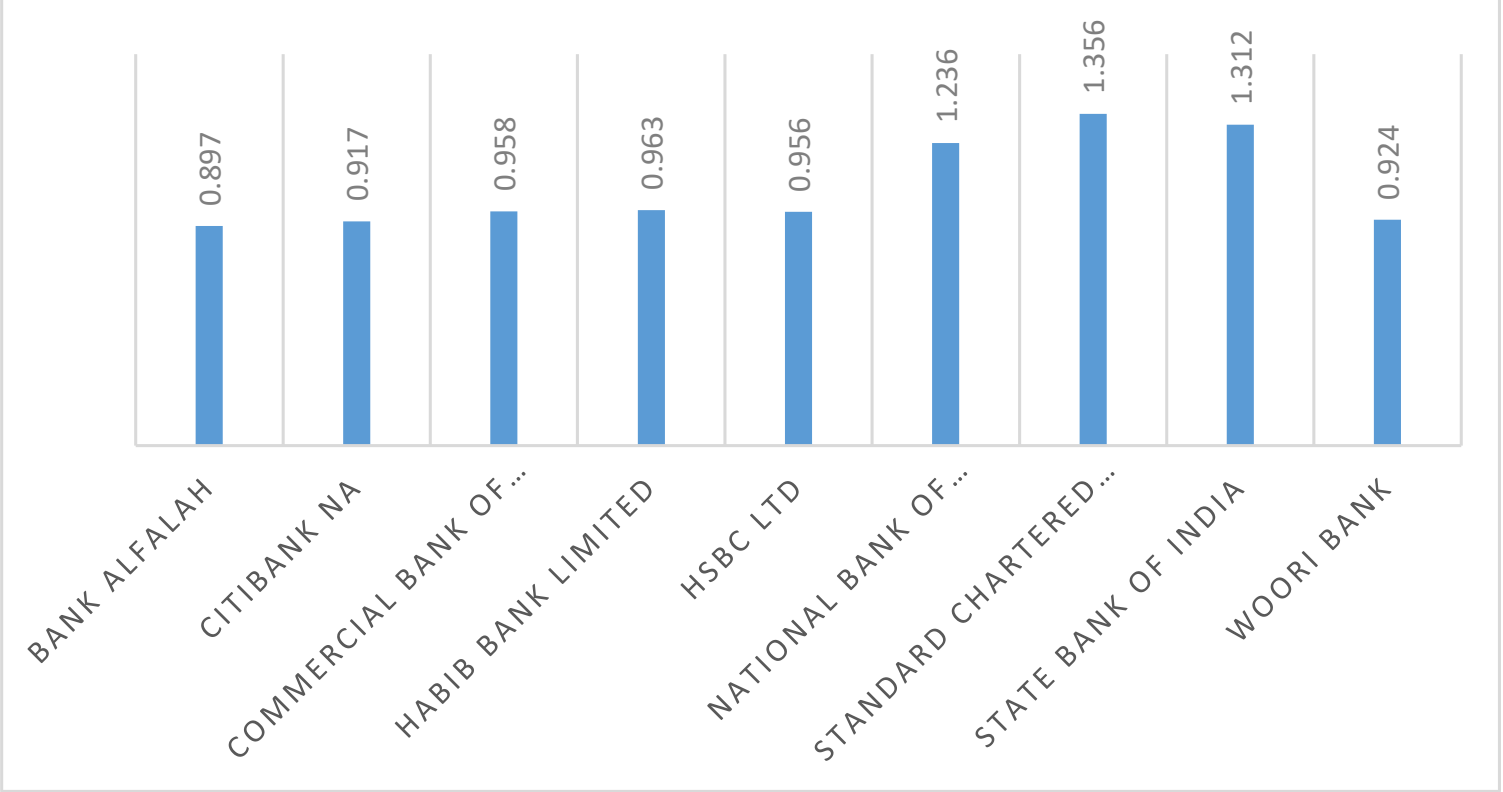

Figure 3. Performance of Foreign Banks' efficiency regarding the technical efficiency 
Figure 3 shows that most ( 6 banks out of 9 banks) of the foreign banks runs their operations with an inefficient position like as bank al falah (Score: 0.897), Citi bank n.a. (Score: 0.917), commercial bank of Ceylon (Score: 0.958), Habib bank limited (Score: 0.963), HBBC bank (Score: 0.956), and Woori bank (Score: 0.924). Furthermore, only three foreign banks are achieved efficient scores by their proper combination of inputs and gaining maximum outputs. These are a national bank of Pakistan (Score: 1.236), state bank of India (Score: 1.312), and standard chartered bank (Score: 1.356). However, the analysis also shows the lower performer foreign bank is bank al falah (Score: 0.897) and the highest performer bank is a standard chartered bank (Score: 1.356).

\section{Efficient Banks Regarding Malmquist Geometric Mean Values}

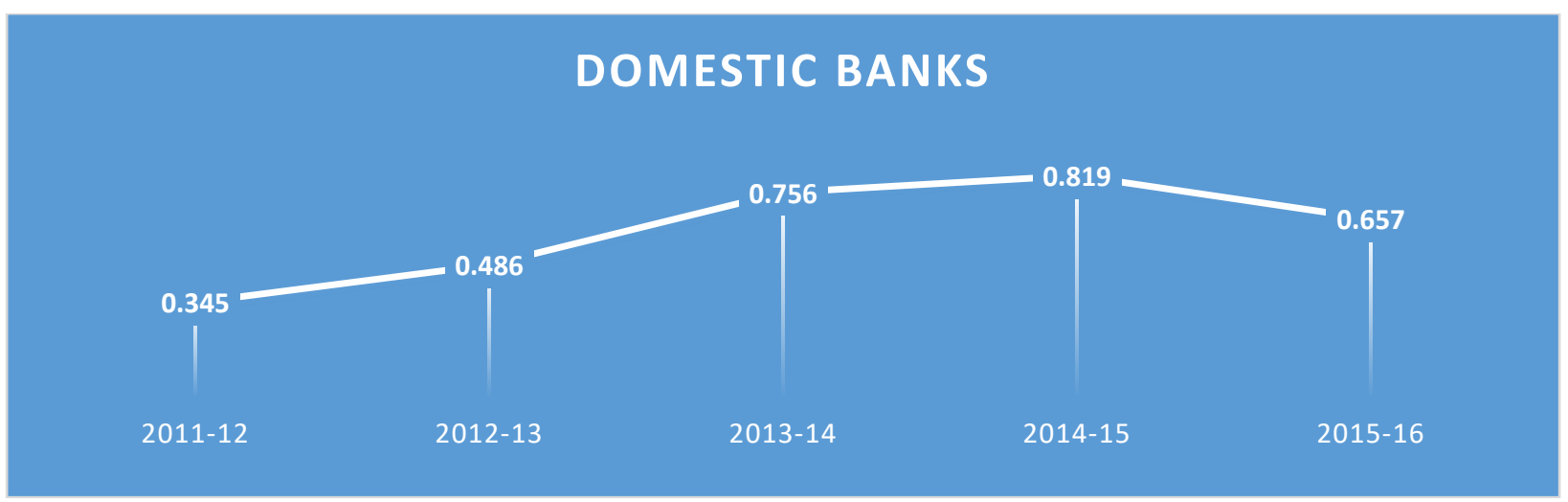

Figure 4. Average Performance of all Domestic Banks' efficiency regarding the technical efficiency for 2011-2016 periods.

Figure 4 discloses that on average the banking sector (all commercial banks) in Bangladesh are inefficient according to the average Malmquist geometric mean values for the whole 2011-2016 periods. These scores are less than one and inefficient as shown in figure 4. The score are .345 (2012) to $.486(2013)$ to $.756(2014)$ to $.819(2015)$ and $.657(2016)$. It can be concluded that from 2011 to 2015 , banking performance tries to raise by the combination of all an efficiency tools though it's could not achieve efficient position. In 2016, this performance shows a downward position for conducting poor performance. Its inefficient score is 0.657 which is 0.162 lower than previous years.

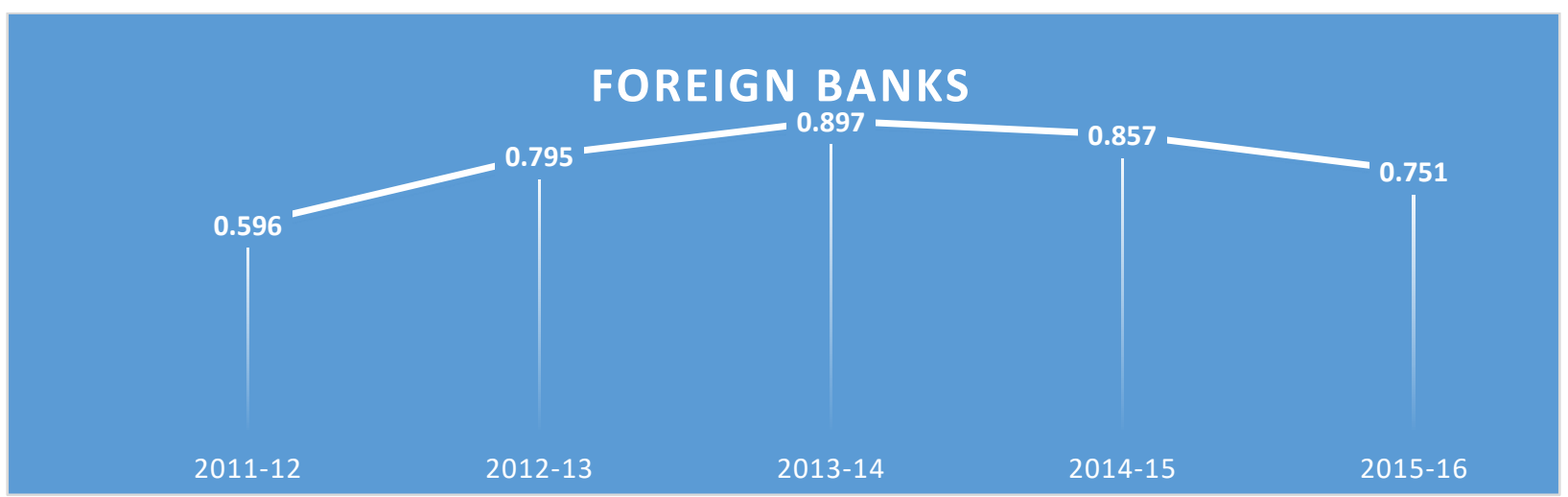

Figure 5. Average Performance of all Foreign Banks' efficiency regarding the technical efficiency for 2011-2016 periods. 
Figure 5 shows that the average performance of all foreign commercial banks from 2011 to 2016. The geometric mean value shows that, the inefficient performance of the foreign banking sector in Bangladesh. Its ratio is .596 to .795 to .897 to .857 to .751 from 2012 to 2016 . It is noticed that the inefficient score gradually increases from 2011 to 2014 but its score again decreases in 2016 for inefficient operations.

\section{SUMMARY OF THE KEY FINDINGS}

This paper summarizes that most of the banks are conducting their operations in an inefficient position due to negative change the efficiency, allocative efficiency, technical efficiency, pure efficiency ratio. The key findings are as follows:

- Only six banks (4 domestic banks and 2 foreign banks) achieved their efficient position among the 36 commercial banks in Bangladesh (including domestic and foreign banks) during the study periods. The best performer domestic bank is Dutch Bangla Bank Limited (DBBL) (Score 1.035) and the foreign bank is Standard Chartered Bank Limited (score 1.658).

- Only five domestic commercial banks' productivity growth is positive for changing efficiency, and technical efficiency and scale efficiency properly. These banks are Islami Bank Bangladesh Limited (IBBL), Dutch Bangla Bank Limited (DBBL), Bank Asia Limited, BRAC Bank Limited, and $\mathrm{AB}$ Bank Limited respectively.

- Similarly, the productivity change is progressed positively only in the three foreign banks (standard chartered bank Limited, Citi bank N.A., and HSBC) among the selected foreign banks that are conducted their operations and services in Bangladesh.

- According to the technical efficiency, Dutch Bangla Bank Limited achieved the highest efficient position among the domestic commercial bank while social Islami bank limited and Mercantile bank Limited stayed in the lowest efficient position. Moreover, the highest performer foreign bank is a standard chartered bank in the category of technical efficiency.

- This study did not find any single bank as efficient in all categories (allocative efficiency, technical efficiency, pure efficiency ratio) for the whole study period (2011-2016).

\section{CONCLUSION AND POLICY IMPLICATIONS}

Bangladesh is a lower-middle-income country whose financial sector has 61 commercial banks. This paper examines the allocative efficiency, technical efficiency, pure efficiency of the 36 commercial banks (27 Domestic and 9 Foreign Banks) through variable returns to scale (VRS) by the Data Envelopment Analysis (DEA) model. It analyzed the secondary panel data collected from Bangladesh Bank, Bank scopes, and individual banks web sites. This study finds that the overall banking industry is inefficient in terms of allocative efficiency, technical efficiency, pure efficiency (both domestic and foreign commercial banks) in Bangladesh. Its score varies between 0.596 and .897 during the study periods. Only six banks (4 domestic banks and 2 foreign banks) achieved their efficient position among the 36 commercial banks in Bangladesh (including domestic and foreign banks) during the study periods. Finally, the study concluded that the Dutch Bangla bank limited is the best efficient bank in Bangladesh based on its strong efficiency, productivity growth, and technical efficiency score but its efficiency score decreasing gradually (1.195 to 1.035$)$ that is 0.16 lower than the previous year efficiency score. It indicates a decreasing return to scale on the banking industry in Bangladesh. This effect is not better to run efficient banking operations. This paper has two major policy implications. Firstly, It will help the banking sector, internal managers, and shareholders to take the right decision in policy-making to ensure their banks' profits. Secondly, it will motivate the owner of commercial banks to concentrate on investors as well as customers by diversifying total bank business operations for better performance and efficiency. 


\section{REFERENCES}

Akber, S. M. (2019). Influential Factors Responsible for Profitability: A Technical Study on Commercial Banks in Bangladesh. International Journal of Accounting \& Finance Review, 4(2), 22-28. https://doi.org/10.46281/ijafr.v4i2.418

Athanasoglou, P. P., Brissimis, S. N., \& Delis, M. D. (2008). Bank-specific, industry-specific and macroeconomic determinants of bank profitability. Journal of International financial Markets, Institutions and Money, 18(2), 121-136.

Azad, M. A. K., Munisamy, S., Masum, A. K. M., Saona, P., \& Wanke, P. (2017). Bank efficiency in Malaysia: a use of malmquist meta-frontier analysis. Eurasian Business Review, 7(2), 287-311.

Bangladesh Bank, B. (2021). Banks and FIs. Retrieved from https://www.bb.org.bd/en/index.php/financialactivity/bankfi

Bangladesh Bank (2020), Developments of Islamic Banking in Bangladesh, October-December 2020. Retrieved from https://www.bb.org.bd/pub/quaterly/islamic_banking/oct-dec2020.pdf

Banna, H., Ahmad, R., \& Koh, E. H. (2017). Determinants of commercial banks' efficiency in Bangladesh: does crisis matter? The Journal of Asian Finance, Economics, and Business, 4(3), $19-26$.

Baten, M. A., \& Mat Kasim, M. (2015). Efficiency and productivity change of selected online banks in Bangladesh: A non-parametric Malmquist approach. Journal of Internet Banking and Commerce, 20(3), 1-6.

Berger, A. N., \& Humphrey, D. B. (1997). Efficiency of financial institutions: International survey and directions for future research. European journal of operational research, 98(2), 175-212.

Bhattarai, B. (2018). Assessing Banks Internal and Macroeconomic Factors as Determinants of Non- Performing Loans: Evidence from Nepalese Commercial Banks. International Journal of Accounting \& Finance Review, 3(1), 13-32. https://doi.org/10.46281/ijafr.v3i1.28

Bonin, J. P., Hasan, I., \& Wachtel, P. (2005). Bank performance, efficiency and ownership in transition countries. Journal of banking \& finance, 29(1), 31-53.

Girardone, C., Molyneux, P., \& Gardener, E. P. (2004). Analysing the determinants of bank efficiency: the case of Italian banks. Applied Economics, 36(3), 215-227.

Haddad, A., Ammari, A. E., \& Bouri, A. (2019). Impact of the Ownership Structure on the Financial Performance of Banks: Comparative Study between Conventional and Islamic Banks. International Journal of Accounting \& Finance Review,4(2), 50-63. https://doi.org/10.46281/ijafr.v4i2.442 
Hossain, B. (2019). Deadweight Loss in the Interest-based and the Interest-Free (Islamic) Microfinance Programs: A Comparative Analysis. Uluslararası Íslam Ekonomisi ve Finansı Araştırmaları Dergisi, 5(2), 49-71.

Hossain, B., \& Wadood, S. N. (2020). Potential Unexplored? Tourism and Economic Growth of Bangladesh. Journal of Tourismology, 6(1), 63-77.

International Monetary Fund. (2021). World Economic Outlook Database. Retrieved from https://www.imf.org/en

Kalsie, A., Dhamija, J., \& Arora, A. (2020). The Measure of Financial Stability and its Impact on Foreign Direct Investment: Evidence from BRIC Nations. International Journal of Accounting \& Finance Review, 5(2), 80-93. https://doi.org/10.46281/ijafr.v5i2.797

Mahmood, M. (2019). The current state of the banking industry in Bangladesh. Retrieved from https://thefinancialexpress.com.bd/views/views/the-current-state-of-the-banking-industry-inbangladesh1556380055\#: :text=Bangladesh\%27s\%20banking\%20system\%20is\%20now\%20faced\%20wit h\%20a,anything\%20but\%20getting\%20any\%20better\%20largely $\% 20$ due $\% 20$

Masood, O., \& Ashraf, M. (2012). Bank-specific and macroeconomic profitability determinants of Islamic banks. Qualitative Research in Financial Markets.

Mirzaei, A., Moore, T., \& Liu, G. (2013). Does market structure matter on banks' profitability and stability? Emerging vs. advanced economies. Journal of Banking \& Finance, 37(8), 2920-2937.

MRA. (2020). List of Licensed MFIs Retrieved from http://mra.gov.bd/index.php?option=com_content\&view=article\&id=115\&Itemid=95

Muhammad Masum, A. K., Azad, M. A. K., Hoque, K. E., \& Beh, L.-S. (2015). Domestic banks in Bangladesh could ensure efficiency by improving human resource management practices. PloS one, 10(7), e0121017.

Rashedul, H. M., \& Israt, R. M. (2012). Data envelopment analysis of banking sector in Bangladesh. Russian Journal of Agricultural and Socio-Economic Sciences, 5(5).

Samad, A. (1999). Comparative efficiency of the Islamic bank vis-à-vis conventional banks in Malaysia. IIUM Journal of Economics and Management, 7(1), 1-27.

Samad, A. (2019). Determinants of Efficiency of the Islamic Banks of Bangladesh during 2008-2012. Journal of Islamic Banking and Finance, 7(1), 1-13.

Sarker, H. (March 16, 2020), Job creation scenario in the banking sector. Retrieved from https://thefinancialexpress.com.bd/views/job-creation-scenario-in-the-banking-sector1584373890 
Solaiman, G., Kadar, A., Wanke, P., \& Azad, A. K. (2017). Bank efficiency in Saudi Arabia: examining the impact of the global financial crisis. Central Europian Review of Economics and Management, 1(4), 69-86.

Sufian, F., \& Kamarudin, F. (2014). Efficiency and returns to scale in the Bangladesh banking sector: Empirical evidence from the slack-based DEA method. Asia-Pacific Journal of Business, 5(1), $1-11$.

Sufian, F., Kamarudin, F., \& Noor, N. H. H. M. (2013). Assessing the Revenue Efficiency of Domestic and Foreign Islamic Banks: Empirical Evidence from Malaysia. Jurnal Pengurusan, 37.

Suzuki, Y., \& Adhikary, B. K. (2010). A 'bank rent' approach to understanding the development of the banking system in Bangladesh. Contemporary South Asia, 18(2), 155-173.

The Financial Express. (May 24, 2021), Bangladesh surpasses India on per capita income. Retrieved from https://thefinancialexpress.com.bd/economy/bangladesh-surpasses-india-on-per-capitaincome

1621610135\#: :text=Bangladesh\%27s\%20per\%20capita\%20income\%20is,per\%20capita\%20i ncome $\% 20$ was $\% 20 \% 242 \% 2 \mathrm{C} 064$.

Tanwar, J., Seth, H., Vaish, A. K., \& Rao, N. V. M. (2020). Revisiting the Efficiency of Indian Banking Sector: An Analysis of Comparative Models Through Data Envelopment Analysis. Indian Journal of Finance and Banking, 4(1), 92-108. https://doi.org/10.46281/ijfb.v4i1.585

Uddin, S. S., \& Suzuki, Y. (2014). The impact of competition on bank performance in Bangladesh: an empirical study. International Journal of Financial Services Management 2, 7(1), 73-94.

\section{APPENDICES}

Appendix A: Overall bank efficiency change values: Malmquist index summary data table

\begin{tabular}{|l|l|l|l|l|l|}
\hline $\begin{array}{l}\text { Banks (Domestic Banks \& } \\
\text { Foreign Banks) }\end{array}$ & $\mathbf{2 0 1 1 - 1 2}$ & $\mathbf{2 0 1 2 - 1 3}$ & $\mathbf{2 0 1 3 - 1 4}$ & $\mathbf{2 0 1 4 - 1 5}$ & $\mathbf{2 0 1 5 - 1 6}$ \\
\hline AB Bank Limited & 0.913 & 0.958 & 0.856 & 0.975 & 1.034 \\
\hline Bank Asia Limited & 0.897 & 0.919 & 1.119 & 0.963 & 0.995 \\
\hline BRAC Bank Limited & 0.891 & 0.956 & 0.963 & 0.986 & 1.058 \\
\hline Dutch Bangla Bank Limited & 0.942 & 0.895 & 0.936 & 1.195 & 1.035 \\
\hline Eastern Bank Limited & 0.537 & 0.819 & 0.895 & 0.819 & 0.895 \\
\hline IFIC Bank Limited & 0.515 & 0.675 & 0.956 & 0.819 & 0.975 \\
\hline Mercantile Bank Limited & 0.890 & 0.886 & 0.819 & 1.2587 & 0.975 \\
\hline Mutual Trust Bank Limited & 0.573 & 0.819 & 0.845 & 0.897 & 0.924 \\
\hline National Bank Limited & 0.641 & 0.687 & 0.986 & 0.895 & 0.928 \\
\hline NCC Bank Limited & 0.790 & 0.865 & 0.986 & 0.819 & 0.831 \\
\hline NRB Bank Limited & 0.595 & 0.895 & 0.916 & 0.975 & 0.745 \\
\hline NRB Commercial Bank Limited & 0.721 & 0.819 & 1.058 & 0.975 & 0.854 \\
\hline NRB Global Bank Limited & 0.602 & 0.675 & 0.948 & 1.245 & 0.756 \\
\hline
\end{tabular}




\begin{tabular}{|l|l|l|l|l|l|}
\hline One Bank Limited & 0.713 & 0.775 & 0.975 & 0.986 & 0.958 \\
\hline Prime Bank Limited & 0.7884 & 0.827 & 0.927 & 0.986 & 0.943 \\
\hline Pubali Bank Limited & 0.661 & 0.775 & 0.975 & 0.996 & 0.976 \\
\hline Southeast Bank Limited & 0.752 & 0.895 & 0.975 & 0.963 & 0.895 \\
\hline The City Bank Limited & 0.886 & 0.975 & 0.927 & 1.006 & 0.975 \\
\hline Trust Bank Limited & 0.891 & 0.897 & 0.975 & 0.819 & 0.874 \\
\hline United Commercial Bank Limited & 0.838 & 0.895 & 0.975 & 0.975 & 0.986 \\
\hline Uttara Bank Limited & 0.729 & 0.819 & 0.927 & 0.975 & 0.986 \\
\hline Al-Arafah Islami Bank Limited & 0.650 & 0.795 & 0.963 & 0.927 & 0.916 \\
\hline EXIM Bank Limited & 0.661 & 0.775 & 0.956 & 0.975 & 0.916 \\
\hline First Security Islami Bank Limited & 0.628 & 0.805 & 0.936 & 0.975 & 0.856 \\
\hline ICB Islamic Bank & 0.439 & 0.486 & 0.975 & 0.963 & 0.963 \\
\hline Islami Bank Bangladesh Limited & 1.017 & 0.963 & 0.986 & 1.356 & 1.021 \\
\hline Shahjalal Islami Bank Limited & 0.617 & 0.956 & 0.825 & 0.836 & 0.936 \\
\hline Social Islami Bank Limited & 0.656 & 0.936 & 0.817 & 0.981 & 0.875 \\
\hline Bank Alfalah & 0.596 & 0.897 & 0.897 & 0.986 & 0.751 \\
\hline Citibank NA & 1.213 & 1.197 & 0.917 & 1.086 & 0.931 \\
\hline Commercial Bank of Ceylon & 0.718 & 0.795 & 0.958 & 0.986 & 0.957 \\
\hline Habib Bank Limited & 0.697 & 0.819 & 0.963 & 0.916 & 0.965 \\
\hline HSBC Limited & 1.074 & 0.975 & 0.956 & 0.916 & 1.258 \\
\hline National Bank of Pakistan & 0.991 & 0.975 & 1.236 & 0.867 & 0.948 \\
\hline Standard Chartered Bank & 1.196 & 1.207 & 1.035 & 0.975 & 1.658 \\
\hline State Bank of India & 0.863 & 0.823 & 1.012 & 0.945 & 0.845 \\
\hline
\end{tabular}

\section{Source: Author's Calculation}

\section{Copyrights}

Copyright for this article is retained by the author(s), with first publication rights granted to the journal. This is an open-access article distributed under the terms and conditions of the Creative Commons Attribution license (http://creativecommons.org/licenses/by/4.0/) 